\title{
Laboratory Scale Production of bio-oil from Oscillatoria algae and its Application in Production of biodiesel
}

\author{
Amisha Malaviya, Megha Shetty, Mikael Varghese, Prachi Bhatia*
}

Department of Biotechnology, Kishinchand Chellaram College, University of Mumbai, Mumbai, Maharashtra, India

\section{Article Info}

Volume 8, Issue 2

Page Number : 243-250

\section{Publication Issue}

March-April-2021

\section{Article History}

Accepted : 20 March 2021

Published : 25 March 2021

\begin{abstract}
Conventional sources of fuels such as diesel and petroleum are threatening to the global climate. They are non-renewable and highly toxic sources of energy which are depleting at an alarming rate due to their high demand. Thus, there is an urgent requirement for alternate sources. Many such renewable, less toxic, and inexpensive solutions are available, including biodiesel from macroalgae. Algal cells contain 50\% intracellular lipids in them which plays an important role in their use as a substrate for production of biodiesel. Oscillatoria is a genus of one such Blue Green Algae (BGA) usually found floating on the surface of fresh water sources such as pond, lakes, rivers and streams. Oscillatoria algae was isolated from pond water and grown in selective media for blue-green alga: BG11 and Chu's medium. The algae were allowed to grow to reach a high cell density to obtain maximum lipid concentration. It was then dried to form a fine powder. The fine algal powder was then used to extract its lipid content or "biooil" employing Soxhlet Apparatus using petroleum ether as the solvent. Alternatively, the bio-oil was also extracted using Solvent extraction with the above solvent using a separating funnel. The verification of the obtained bio-oil was carried out by estimating its Rf or retardation factor using Thin Layer Chromatography (TLC). Transesterification of the bio-oil was carried out using methanol in presence of potassium hydroxide catalyst using a condensation reaction giving crude biodiesel and glycerol as the products. This biodiesel can be purified industrially and can be used as an energy source of the future.
\end{abstract}

Keywords: Algae, Oscillatoria, Soxhlet, TLC, Biodiesel

\section{INTRODUCTION}

Fossil fuels can be defined as a class of hydrocarbon containing biological materials occurring within the earth's crust which are to this day used as the primary source of energy. There are various disadvantages of fossil fuels such as land degradation, water pollution, toxic emissions, and global warming. Biodiesel is a clean and renewable fuel which can be used as the ideal fossil fuel substitute which can be used either in 
the pure form or it in the blended form with petrol/diesel. The various advantages of biodiesel include reduced greenhouse emissions; it is nontoxic as well as biodegradable and most of all that it is a renewable source of energy.

Algae are simple organisms, ranging from microscopic to macroscopic in size, usually found in or on the surface of water. These organisms possess the unique capability of performing photosynthesis by utilizing energy from the sun, and carbon dioxide from the atmosphere to produce oxygen. They can be regarded as the common source responsible for the photosynthetic machinery in both plants and algae, which makes them both agriculturally as well as environmentally important. Cyanobacteria ("BlueGreen Algae"), such as Oscillatoria sp., are a heterogeneous group of bacteria found almost everywhere but majorly occur in freshwater systems. They are usually un-branched with a filamentous body and derive their name from their characteristic slow, rhythmic oscillating movement.

Algae possess a wide range of applications such as: Algae play a critical role in the aquatic ecosystem as they are the major food producers and help the organisms thrive in lakes, ponds, and streams. They can be employed in wastewater and environmental bioremediation. Algae have also shown a potential application in the food industry, pharmaceutical industry, and the cosmetic industry. However, the most important application of algae is the ability to produce Biofuel/Biodiesel which is largely due to their rapid growth rate and high lipid content. Biodiesel from algae can be produced by a process known as Transesterification, which is a reaction between the algal bio-oil and an alcohol (methanol) in the presence of a catalyst $(\mathrm{KOH})$. This reaction of transesterification produces two final products glycerol as the top layer and the corresponding ester called biodiesel. The work aims to produce a renewable, less toxic, and inexpensive solution using algal biomass to create a sustainable biofuel as a replacement to traditional sources of energy.

\section{METHODS AND MATERIAL}

\section{Isolation of Oscillatoria sp. from pond water and incubation.}

\section{Collection of samples.}

Various visible green algae samples were collected from the surface of stagnant freshwater bodies: Tulsi lake in Sanjay Gandhi National Park, Vasai lake in Vasai, Banganga lake in Walkeshwar.

\section{Sample identification using wet mount technique.}

A nichrome loop was used to obtain the organisms from the bottom of each of the bottle containing the algae. Smears of the samples were placed on a clean grease free slide and covered with a coverslip/ a drop of cedar wood oil was added and observed under 40x lens. The slides were then examined under the microscope and all the observations were recorded. The selected strain was identified based on the cultural and morphological characteristics as observed under the microscope.

\section{Sample preparation}

The visible green portion from the water samples was carefully obtained by removing the top clear layer of water.

A suspension of the same was prepared in $1 \mathrm{ml}$ of Sterile saline, which was then added to Sterile BlueGreen 11 (BG11) media broth and half strength Chu's medium broth. This media was then incubated at room temperature for 5-7 days in presence of sunlight.

\section{Screening of various liquid media for maximum growth.}

Selection of media 
For maximal growth of the algae, two media broths were selected- Blue-Green 11 (BG11) media and half strength Chu's media broth.

\section{Medium preparation}

All the above media were prepared in $250 \mathrm{ml}$ flasks. All the components were dissolved in distilled water, the $\mathrm{pH}$ was adjusted and autoclaved at $121^{\circ} \mathrm{C}$ for $1 \mathrm{hr}$.

\section{Inoculum preparation and incubation time and} temperature

A loopful of culture was picked up from the collected sample and added to the flasks containing the media. Optimal incubation time was determined by incubating the inoculated media for a total period of 5-7 days at room temperature $\left(28 \pm 2^{\circ} \mathrm{C}\right)$ with plenty of direct sunlight.

The growth of the samples was determined using a spectrophotometer and a growth curve was plotted accordingly based on which, BG11 media was selected as a suitable media for further cultivation.

\section{$\mathrm{pH}$ of the medium}

The $\mathrm{pH}$ of pond water was found to be 7 which is neutral using a $\mathrm{pH}$ paper. Hence, care was taken to maintain the $\mathrm{pH}$ of the media's used- BG11 and Half strength Chu's media to $\mathrm{pH} 7$ to provide similar environmental conditions for the optimum growth of algae.

\section{Cell harvesting from the media.}

Oscillatoria growing in the broth was harvested using high speed centrifugation. The media containing the cells was transferred from the flask to clean and dry falcon tubes of $10 \mathrm{ml}$ volume. These tubes were then placed in a centrifuge and centrifuge at $5000 \mathrm{rpm}$ for 15 minutes. On completion of centrifugation, the tubes were carefully removed. The supernatant was discarded, and the pellet was collected. Cells of the pellet will now be disrupted using two methods, heating in a microwave and manual grinding which will help break the outer cell membrane of the organism and allow the contents to flow out in the media.

\section{Disruption of the cells to release lipids.}

Disruption of the cells was done using two methods, heating using a microwave and manual grinding with solvent.

Microwave heating: The pellet obtained from centrifugation was added in a $250 \mathrm{ml}$ flask and heated using a microwave oven at a high temperature, about $100{ }^{\circ} \mathrm{C}$ and $2,450 \mathrm{MHz}$ for $5 \mathrm{mins}$. This method helps break the outer cell membrane of the organism and allows the contents to flow out in the media.

Manual grinding: Manual grinding of the pellet was carried out using a mortar and pestle with petroleum ether solvent.

\section{Production of bio-oil}

\section{Drying of the pellet obtained}

The pellet obtained was dried completely in a hot air oven at $55^{\circ} \mathrm{C}$ for 2 hours.

\section{Bio-oil production by solvent extraction using a separating funnel.}

Petroleum ether is used as a solvent to separate the lipid components from the rest of the cell materials. $100 \mathrm{ml}$ of petroleum ether was added to a separating funnel (volume $250 \mathrm{ml}$ ) containing $50 \mathrm{ml}$ of the disrupted algal sample and mixed thoroughly. This was then allowed to settle for 3 days without any disturbance. Upon incubation, 3 layers were obtained. The lowermost layer contained the cell debris, middle layer contained the desired lipids, and the topmost layer contains the solvent. The contents of these three layers were extracted carefully and the middle lipid layer was used for further processing. Upon separation, the middle layer containing oil was carefully extracted from the funnel and oil yield efficiency can be measured using the formula: 
Extracted oil efficiency $(\%)=[($ Volume of oil extracted)/ (The total volume of algae) $] \times 100$

Algal oil can be efficiently extracted using chemicals by extraction method. Solvent Extraction technique is favoured than mechanical pressing method since it recovers all the oil leaving just $0.5-0.7 \%$ leftover oil in the algae biomass.

\section{Production of Bio-oil using Soxhlet extraction.}

Soxhlet extraction is used since the desired compound has significant solubility in petroleum ether solvent. $50 \mathrm{~g}$ of the dried and powdered algae was placed in a Whattman filter paper made into a thimble. This was then placed in a Soxhlet extractor. The Soxhlet was then equipped with condenser setup. A round bottom flask was filled with solvent petroleum ether in the ratio 1:2. The solvent was heated to many refluxes for three hours at $60^{\circ} \mathrm{C}$. After such reflux cycles, a portion of oil was dissolved in hexane. This solution along with the insoluble portion of the algae remained in the thimble.

\section{Testing of algal oil components using Thin Layer Chromatography}

Thin layer chromatography was employed to check for the presence of lipids in the sample obtained. 202 $\mathrm{ml}$ of the solvent system of Hexane: Ether: Acetic acid (60:40:1) was used in a $3000 \mathrm{ml}$ chromatographic chamber to run the sample. The chamber was covered and allowed to saturate for 30 minutes before loading the plates. With a $10 \mu \mathrm{l}$ capillary pipette, spot 1-2 $\mu \mathrm{l}$ of the sample onto the previously prepared silica gel plate making sure the spot remains smaller than $4 \mathrm{~mm}$ in diameter. The spots were allowed to dry making sure that the loading area is above the level of the solvent. The plates were placed in the chamber to develop and the lid was closed immediately. The samples were allowed to run for approximately $60 \mathrm{mins}$, until the solvent front reached the upper line. The plates were removed and placed in the iodine chamber for spotting. Lipids were yellow spots on the plate in 2-5 minutes. The retardation factor ( $\mathrm{Rf})$ was calculated using the following formula:

Retardation factor $(\mathrm{Rf})=$ (Distance travelled by the solute $(\mathrm{cm})) /($ Distance travelled by the solvent $(\mathrm{cm})$ )

Conversion of bio-oil to biodiesel using Transesterification process.

$100 \mathrm{ml}$ of the extracted algal oil was taken in a round bottom flask along with $70 \mathrm{ml}$ of methanol. A catalyst, freshly prepared $0.5 \mathrm{M}$ potassium hydroxide was also added to speed up the reaction. A piece of porcelain was added to the round bottom flask to have uniform boiling throughout the solution and avoid bumping of the solution due to uneven heating. This flask was then affixed with a condenser setup and placed on a heating mantle. The temperature of the mantle was set to $60^{\circ} \mathrm{C}$ and was switched on. The reaction was left to be carried out for 2 hours making sure that the condenser does not overheat. At the end of 2 hours, the flask was left to cool at room temperature and 2 layers were obtained-The upper layer containing glycerol while the lower layer containing crude biodiesel which can be further purified using water and dry washing technologies.

\section{III.RESULTS AND DISCUSSION}

\section{Sample collection and identification of the algal species}

Various visible green algal samples were collected from the surface of stagnant fresh water bodies (Tulsi Lake, Walkeshwar Lake,Vasai Lake) and were identified using wet mount technique. The sample was examined under the microscope and was found to be Oscillatoria algal species due to the presence of the distinct hyphae. All 3 samples showed distinct Oscillatoria characters. This work can also be compared with Darienko et al., (2010)

Screening of media for maximum growth 
For maximising the growth of the algae, 2 different media broths: Blue green 11 media which is a universal medium and half strength Chu's media were chosen. After incubating the 3 samples for 7 days, their growth was studied in BG-11 and half strength Chu's media, using a growth curve. Media for maximum growth of the cells was chosen based on the growth curve plotted using absorbance at 540nm measured by the UV spectrophotometer. Absorbance readings and growth curve for algal samples in BG-11 Media and Chu's media is given below. Similar studies were carried out by Chand Shah et al. (2012) and Rai et al. (2014) where they have used half strength Chu's media and BG-11 media for the screening and growth of green algae species. Absorbance readings and Growth curve of BG 11 media and half strength Chu's media is given in table 1 and table 2 .

TABLE 1. ABSORBANCE READINGS FOR ALGAL SAMPLES IN BG 11 MEDIA

\begin{tabular}{|l|l|l|l|}
\hline \multirow{2}{*}{$\begin{array}{l}\text { e } \\
\text { (in } \\
\text { in } \\
\text { days }\end{array}$} & $\begin{array}{c}|c| \\
\text { Sample }\end{array}$ & $\begin{array}{c}\text { Absorbance at } 540 \mathrm{~nm} \\
\text { sample }\end{array}$ & $\begin{array}{c}\text { Walkeshwar } \\
\text { lake sample }\end{array}$ \\
\cline { 2 - 4 } & & & \\
\hline $\mathbf{1}$ & 0.050 & 0.31 & 0.62 \\
\hline $\mathbf{2}$ & 0.042 & 0.48 & 0.12 \\
\hline $\mathbf{3}$ & 0.023 & 0.29 & 0.17 \\
\hline $\mathbf{4}$ & 0 & 0.3 & 0 \\
\hline $\mathbf{5}$ & 0 & 0 & 0 \\
\hline $\mathbf{6}$ & 0 & 0 & 0 \\
\hline $\mathbf{7}$ & 0 & 0 & 0 \\
\hline
\end{tabular}

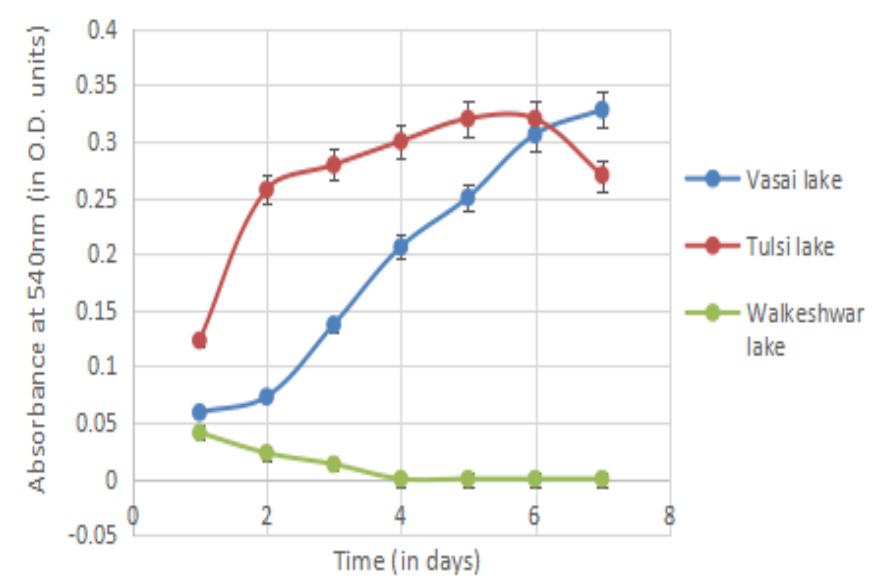

FIGURE 1. GROWTH CURVE OF OSCILLATORIA IN BG 11 MEDIA

TABLE 2. ABSORBANCE READINGS FOR ALGAL SAMPLES IN HALF STRENGTH CHU'S MEDIA.

\begin{tabular}{|c|c|c|c|}
\hline \multirow{2}{*}{$\begin{array}{l}\text { Time } \\
\text { (in } \\
\text { days) }\end{array}$} & \multicolumn{3}{|c|}{ Absorbance at $540 \mathrm{~nm}$} \\
\hline & $\begin{array}{c}\text { Vasai lake } \\
\text { sample }\end{array}$ & $\begin{array}{c}\text { Tulsi lake } \\
\text { sample }\end{array}$ & $\begin{array}{l}\text { Walkeshwar } \\
\text { lake sample }\end{array}$ \\
\hline 1 & 0.059 & 0.123 & 0.041 \\
\hline 2 & 0.073 & 0.257 & 0.023 \\
\hline 3 & 0.137 & 0.279 & 0.013 \\
\hline 4 & 0.206 & 0.3 & 0 \\
\hline 5 & 0.25 & 0.32 & 0 \\
\hline 6 & 0.306 & 0.32 & 0 \\
\hline 7 & 0.328 & 0.27 & 0 \\
\hline
\end{tabular}

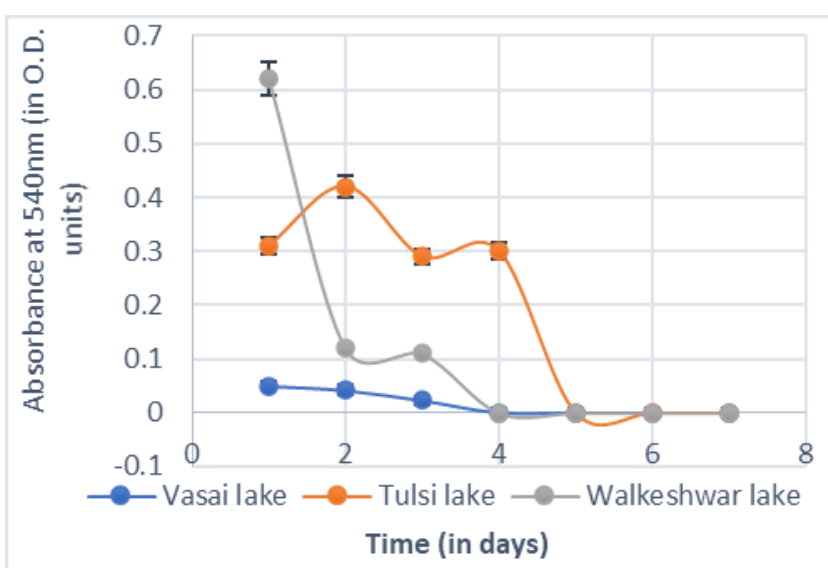

FIGURE 2. GROWTH CURVE OF OSCILLATORIA IN HALF STRENGTH CHU'S MEDIA

Since Vasai lake samples showed the most preferable growth curve in BG-11 Media, it was chosen as the most suitable for the project. 


\section{Cell Harvesting.}

Cell harvesting was done by centrifugation at 5000rpm for 15 mins and this method separates the media into two layers upper layer contained the media and lower layer contained the algal cells.

\section{Collection and disruption of cells to release the lipids.}

Cell disruption is done to obtain the intracellular fluid without disrupting any of its components. Cell wall disruption is considered essential to release the carbohydrates and sugars to maximise biodiesel yields. Cell disruption method was carried out to release the lipids from the Oscillatoria species. 2 methods were used for cell disruption: Manual Grinding and Microwave. Microwave heating at $100^{\circ} \mathrm{C}$ at $5 \mathrm{~min}$ intervals led to browning of the sample. This may be due to burning of their lipid content. Thus, this method was not used. Manual Grinding method led to formation of lipid bubbles in the ceramic mortar which were then collected in the same way thus manual grinding was used. In the same way Zheng et al., (2011) used manual grinding for the disruption of cells to release lipids.

The solution obtained was dried completely in a hot air oven at 55 degree Celsius for 2 hrs.

\section{Production of Bio-oil}

Production of Bio-oil was done by two methods solvent extraction using a separating funnel and by using Soxhlet extraction. Solvent extraction was found to be more efficient as $100 \mathrm{ml}$ of algal oil was obtained using $250 \mathrm{ml}$ of the culture giving an extraction efficiency of $50 \%$ as compared to soxhlet extraction which yielded $12 \mathrm{ml}$ of algal oil with an extraction efficiency of $6 \%$ using the same amount of culture and the same solvent. Earlier studies conducted also confirms that bio-oil production by Soxhlet extraction and by solvent extraction using a separating funnel are effective methods for the extraction of oil from the Oscillatoria algal species. (Konga et al., 2017)

\section{Testing of algal oil components using Thin Layer Chromatography}

Lipid analysis can be done using Thin Layer Chromatography. Algal oil obtained was spotted on the TLC plate and the sample was run in solvent system of Hexane: Ether: Acetic acid (60:40:1) was used in a $3000 \mathrm{ml}$ chromatographic chamber. After the TLC plate was run in the solvent system, for the analysis of lipids from the algal oil, it was placed in an iodine chamber for 5 minutes. After which yellow spots were observed. The retardation factor was calculated using the formula and was found out to be 0.46 . This corresponds to the $\mathrm{Rf}$ value that should be obtained for oils, fats, and lipids, 0.5 , according to Harrata et al.,2015.

\section{Conversion of bio-oil to biodiesel using Transesterification Process.}

Transesterification is the process of making biodiesel. In the transesterification process, a glyceride reacts with an alcohol (methanol) in the presence of a catalyst $(\mathrm{KOH})$ forming fatty acid alkyl esters and an alcohol. Alkyl esters obtained act as biodiesel. This technique was performed by adding $70 \mathrm{ml}$ methanol to $100 \mathrm{ml}$ bio-oil in a round bottom flask. On completion of several refluxes that is at the end of 2 hours two layers were obtained in the flask. The upper layer contained glycerol and the lower layer contained crude biodiesel, due to their differences in densities. Similarly, Anastopoulos et al., (2009) converted biooil by using transesterification process.

\section{IV.CONCLUSION}

Oscillatoria Algae was isolated from pond water and grown under laboratory conditions. Two media were employed for achieving maximum growth. Blue green 
(BG) 11 media and half strength Chu's media. After incubation and plotting of growth curve, BG 11 media was found to be more favourable for the growth of the algae. Bio-oil was extracted from the algae by Solvent extraction and Soxhlet extraction. Solvent extraction was found to be more efficient with an extraction efficiency of $50 \%$ obtained by using Petroleum ether as the solvent however Soxhlet extraction gave only $6 \%$ efficiency. Lipid analysis of the bio-oil was also performed using Thin layer Chromatography and detection was done using Iodine vapours. A yellow spot was obtained with a $\mathrm{Rf}$ value of 0.46 corresponding to the value that should be obtained. The chemical conversion of bio-oil to biodiesel was carried out by the process of Transesterification using Potassium Hydroxide as a catalyst. An upper layer containing glycerol and a lower layer containing crude biodiesel was obtained. Thus, this Biodiesel extracted from Oscillatoria Algae can potentially prove be a suitable solution for the future as it is less toxic and can meet the everincreasing demand for energy.

Biodiesel is less toxic, biodegradable and a renewable source of energy which can be used as a suitable alternative for petroleum, diesel. Biodiesel can be used in existing diesel engines in form of blends with petroleum diesel and replace fossil fuels as the primary transport energy source.

\section{ACKNOWLEDGEMENT}

In the present world of competition there is a race of existence in which those are having the will to come forward succeed. This project was no different and we owe immense gratitude to all those who helped me. We would like to express our sincere gratitude to Dr. Hemlata Bagla, Principal, K.C. College and Dr. Sejal Rathod, Coordinator, Department of Biotechnology, K.C. College for providing us access to the laboratory and the required facilities. This project would have been impossible without the guidance and support of our mentor, Ms. Prachi Bhatia, Assistant Professor, Department of Biotechnology, K.C. College. We would like to thank her for her encouraging words, valuable experience that has helped us patch this project and make it a full proof success her suggestions and her instructions has served as the major contributor towards the completion of the project. We are immensely grateful for the support rendered by all the teachers of the Biotechnology Department who offered us their valuable suggestions in solving the many obstacles that arose during the course of this project. We would especially like to thank Dr. Yogita Shinde, Department of Chemistry, K.C. College for her expertise in the chemical processes carried out. This would never have been possible without the kindness and invaluable help from the Laboratory assistants. Their constant belief in us has given us the motivation to complete this project successfully.

\section{REFERENCES}

[1]. Anastopoulos, g., zannikou, y., stournas, s., \&kalligeros, s. Transesterification of vegetable oils with ethanol and characterization of the key fuel properties of ethyl esters. Energies, vol.2, issue 2, pp. 362-376, 2009.

[2]. Baig, R. U., Malik, A., Ali, K., Arif, S., Hussain, S., Mehmood, M., Sami, K., Mengal, A. N., \& Khan, M. N. . Extraction of oil from algae for biodiesel production, from Quetta, Pakistan. IOP Conference Series: Materials Science and Engineering, Vol.414, pp. 1-7, 2018.

[3]. Boudh, S., Zainith, S., Chowdhary, P., \& Mishra, S. Biodiesel as a Renewable Energy Source pp. 201-211, 2020.

[4]. Chand Shah, G.Analysis and Characterization of Algal Oil by Using Different Chromatographic Techniques for the Higher Production of Biodiesel from Scenedesmus Dimorphus Algal Species. Journal of Stock \& Forex Trading, Vol. 01, No-8 pp.1-5, 2012. 
[5]. Chen, Z., Wang, L., Qiu, S., \& Ge, S. Determination of Microalgal Lipid Content and Fatty Acid for Biofuel Production. BioMed Research International,Vol. 2018, pp.1-7, 2018.

[6]. Das, P., Khan, S., Chaudhary, A., Abdulquadir, M., Thaher, M., \& Al-Jabri, H. Potential Applications of Algae-Based Bio-fertilizer pp. 41-65, 2019.

[7]. Hannon, M., Gimpel, J., Tran, M., Rasala, B., \& Mayfield, S. Biofuels from algae: Challenges and potential. Biofuels, Vol-1, No-5(5), pp.763-784, 2010.

[8]. Höök, M., \& Tang, X. Depletion of fossil fuels and anthropogenic climate change- $A$ review. Energy Policy, Vol-53, No-1, pp.797-809, 2013.

[9]. 9Isom, L., \& Hanna, M. Biodiesel Current and Future Perspectives. Handbook of Plant-Based Biofuels, pp.177-181, 2008.

[10]. Khan, M. I., Shin, J. H., \& Kim, J. D. The promising future of microalgae: Current status, challenges, and optimization of a sustainable and renewable industry for biofuels, feed, and other products. Microbial Cell Factories, Vol17, No-1, pp.1-21, 2018.

[11]. Manzanera, M., Molina-Munoz, M., \& Gonzalez-Lopez, J. Biodiesel: An Alternative Fuel. Recent Patents on Biotechnology, Vol-2, No-1, pp.25-34, 2008.

[12]. Manieniyan, V., Thambidurai, M., \& Selvakumar, R. Study on Energy Crisis and the Future of Fossil. Shee, pp.7-12, 2009.

[13]. Milledge, J. J., Smith, B., Dyer, P. W., \& Harvey, P. (2014). Macroalgae-derived biofuel: A review of methods of energy extraction from seaweed biomass. Energies, Vol-7, No-11, pp.7194- 7222, 2014.

[14]. Mjalli, F., San, L., Yin, K., \& Hussain, M. Dynamics and Control of Biodiesel Transesterification Reactor. Chemical Engineering \& Technology, Vol.32, pp.13-26, 2009.
[15]. Naik, A. N., Singh, M., \& Qurishi, Y. Algal biofuel: A promising perspective. Annals of Plant Sciences, Vol-7, No-5, pp.2262, 2018.

[16]. Pieprzyk, B., \& Rojas, P. Influence of methane emissions on the GHG emissions of fossil fuels. Biofuels, Bioproducts and Biorefining, Vol.13, No-3, pp.535-551, 2018.

[17]. Priyanka, Kumar, C., Chatterjee, A., Wenjing, W., Yadav, D., \& Singh, P. Cyanobacteria pp. 193-202, 2020.

[18]. Saladini, F., Vuai, S., Langat, B., Gustavsson, M., Bayitse, R., Gidamis, A., Belmakki, M., Owis, A., Rashamuse, K., Sila, D., \& Bastianoni, S. Sustainability assessment of selected biowastes as feedstocks for biofuel and biomaterial production by emergy evaluation in five African countries. Biomass and Bioenergy, Vol.85, pp.100-108, 2015.

[19]. Silva, T. A., Carlos, A., Batista, F., \& Vieira, A. T. A brief discussion of general aspects of Biodiesel Production | Brazilian Geographical Journal: Geosciences and Humanities research medium. January, 2012

[20]. Wright, I. A., Belmer, N., \& Davies, P. J. Coal Mine Water Pollution and Ecological Impairment of One of Australia's Most 'Protected' High Conservation-Value Rivers. Water, Air, and Soil Pollution, Vol.228, No-3, pp.70-90, 2017.

\section{Cite this article as :}

Amisha Malaviya, Megha Shetty, Mikael Varghese, "Laboratory Scale Production of bio-oil from Oscillatoria algae and its Application in Production of biodiesel ", International Journal of Scientific Research in Science and Technology (IJSRST), Online ISSN : 2395-602X, Print ISSN : 2395-6011, Volume 8 Issue 2, pp. 243-250, March-April 2021. Available at doi : https://doi.org/10.32628/IJSRST218228 Journal URL : https://ijsrst.com/IJSRST218228 